Silvia Notarfonso (Budapest/Macerata)

\title{
Crypto-Christianity and Religious Hybridisation in the Ottoman Balkans: a Case Study (1599-1622)
}

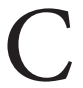
atholic confessionalisation in particular and religious identities in general developed some unusual characteristics in the early modern Balkans, at that time the European frontier of the Ottoman empire ${ }^{1}$. In such a context, Catholic missionaries carrying out their pastoral duties, acted as "passeurs culturels" - as Serge Gruzinski and Louise Bénat Tachot would say ${ }^{2}$ - seeking to communicate and mediate between people from different religious and ethnic groups.

At the same time, however, they still were proper guardians of the Roman Catholicism and thus had a twofold task: fideles catholici in catholica fide confirmarentur et schismatici haeresibusque infecti christiani ad fidei catholicae Romanae [...] ad rectam semitam revocarentur atque erudirentur ${ }^{3}$. For that reason, missionaries and apostolic visitors devoted plenty of attention to displays of religious syncretism which they came across. In their reports, for instance, Catholic missionaries describe several cases of hidden Catholicism. What do they mean by using this peculiar definition?

The Albanian scholar Stavro Skendi, in his essay Crypto-Christianity in the Balkans under the Ottomans ${ }^{4}$ defines crypto-Christianity - or hidden Christianity - as the appearance of individuals or groups who, while publicly professing Islam, satisfied their consciences by practising Christianity-Orthodox or Catholic - in private ${ }^{5}$. According to Skendi, this peculiar religious phenomenon is a complicated subject [about which] available information is scarce. If we exclude the reports of Catholic clergymen we are left mainly with fragmentary information from various travellers and researchers ${ }^{6}$.

\footnotetext{
${ }^{1}$ Cf. A. Molnár, Confessionalization on the Frontier. The Balkan Catholics between Roman Reform and Ottoman Reality, Roma 2019; IDEM, Le Saint-Siège, Raguse et les missions catholiques de la Hongrie ottomane 1572-1647, Roma-Budapest 2007.

${ }^{2}$ Cf. L. Bénat Tachot, S. Gruzinski, Passeurs culturels. Mécanismes de métissage, Paris 2001.

${ }^{3}$ M. VAnino, Autobiografija Bartola Kašića [Autobiography of Bartol Kašić], Zagreb 1940 [= GPKH, 15], p. 35.

${ }^{4}$ S. Skendi, Crypto-Christianity in the Balkan Area under the Ottomans, SRev 26.2, 1967, p. 227-246.

${ }^{5}$ Ibidem, p. 227.

${ }^{6}$ Ibidem.
} 
As a matter of fact, Catholic missionaries used to take notes and record the most significant events involving various religious groups living in the Balkans. As it has been demonstrated ${ }^{7}$, those detailed and precious sources of information could help us shed light on the peculiar social and religious system present under Ottoman rule. Skendi himself commented on a variety of examples from missionaries' reports to clarify crypto-Christianity. In this regard, I would like to mention an interesting episode witnessed by Marino Bizzi, appointed as the Archbishop of Antivari in 1608. The Catholic missionary took a trip to Albania and visited the city of Kalevaç. Skendi wrote: he was approached by a Moslem who told him that, although he professed Islam in his heart he held the Christian faith, in which he wanted to live and die ${ }^{8}$.

More recently, Noel Malcolm has discussed and analysed that complicated situation. In his essay Crypto-Christianity and Religious Amphibianism in the Ottoman Balkans. The Case of Kosovo', the author defines this phenomenon as a family tradition, a cultural endowment "transferred from generation to generation" and particularly prevalent in the area covering present day Albania and Kosovo. In this regard it is important to clarify that examples of crypto-Christianity - as proved by missionaries' reports - were not homogeneously widespread throughout the Balkan peninsula, as this vast area was characterised by a serious lack of uniformity in terms of religious communities and ethnic groups, resulting in a kaleidoscopic and entangled environment ${ }^{10}$.

As Malcolm has correctly pointed out, in fact crypto-Christianity is not a genuine example of religious syncretism. He added: in indirect ways the common or borrowed practices of syncretism may have helped to sustain an environment in which it was easier for crypto-Christianity to exist ${ }^{11}$. This is unquestionably true. In fact, we should not forget that, in the Ottoman Balkans, we can also discover examples of crypto-Judaism, as shown, for instance, by Ivan Biliarsky

\footnotetext{
${ }^{7}$ See, for instance A. Ndreca, L'Albania nell' Archivio di Propaganda Fide, Città del Vaticano 2017; G. PIzzorusso, Governare le missioni, conoscere il mondo nel XVII secolo. La Congregazione pontificia De Propaganda Fide, Viterbo 2018; I.G. TóтH, Missionaries as Cultural Intermediaries in Religious Borderland: Habsburg Hungary and Ottoman Hungary in the Seventeenth Century, [in:] Cultural Exchange in Early Modern Europe, vol. I, Religion and Cultural Exchange in Europe, 1400-1700, ed. H. Schilling, I.G. Tóth, Cambridge 2007, p. 25-46. See also N. Malcolm, Kosovo. A Short History, New York 1998.

${ }^{8}$ S. Skendi, Crypto-Christianity in the Balkan Area..., p. 236.

${ }^{9}$ N. Malcolm, Crypto-Christianity and Religious Amphibianism in the Ottoman Balkans. The Case of Kosovo, [in:] Religious Quest and National Identity in the Balkans, ed. H. Norris, M. HePpelL, C. Hawkesworth, London 2001, p. 91-110. See also S. Zefi, Islamizacija Albanaca i fenomen ljaramanstva tijekom stoljeća (XV.-XX.). Razlozi i stav Katoličke crkve [The islamisation of the Albanians and the phenomenon of ljaramanstvo (biconfessionality) down the centuries $\left(15^{\text {th }}-20^{\text {th }}\right)$. Causes and position of the Catholic Church], Zagreb 2003. This work was first published in Albanian in 2000.

${ }^{10}$ Here we will be dealing specifically with manifestations of hidden Christianity from Western and Central Balkans.

${ }^{11}$ N. Malcolm, Crypto-Christianity..., p. 96.
} 
in his studies ${ }^{12}$. Rossitsa Gradeva in her essay Apostasy in Rumeli in the Middle of the Sixteenth Century $y^{13}$ mentions another example of crypto-Christianity from Bulgaria: an Orthodox neo-martyr, Nikolay, who had been converted to Islam (he was forced, according to his Vita) and thus spent nearly twelve months between the two faiths, secretly professing Christianity ${ }^{14}$. Eventually Nikolay rejected Islam and firmly declared himself to be a Christian. Subsequently, he was taken to court, charged with apostasy and put to death.

Such disguised religiosity in early modern Europe did not exist exclusively in the Balkan environment. Let me give another example. In 1970 the Italian historian Carlo Ginzburg published a notable book Il nicodemismo. Simulazione e dissimulazione religiosa nell'Europa del ' $500^{15}$, addressing a similar phenomenon in $16^{\text {th }}$ century Christian Europe, nicodemism. Incidentally, the term 'nicodemite' was introduced by John Calvin in 1543 to define Protestant people living in Catholic lands who observed the Catholic ways to avoid persecution. Episodes of crypto-Judaism and crypto-Islamism also took place in the multi-confessional late medieval and early modern Spain where the Marranos (Jews converted to Catholicism) and Moriscos (Muslim people converted to the Catholic faith) were widely present ${ }^{16}$.

Accounts from Catholic missionaries serving in the Balkans offer plenty of examples of hidden Christianity. In his publication, Malcolm remarked that - based on missionaries' documents - the first evidence of crypto-Christianity dates back to the $17^{\text {th }}$ century. And he refers to an earlier "potential" evidence of hidden Christianity in an Ottoman report of 1568. According to this document, Muslims living in the Debar area used to take their new-born children to priests to give them a Christian name, and then, at another time, they went to the Islamic religious leaders. But, Malcom notes, we cannot tell whether this was proper crypto-Christianity or merely a quasi-magical syncretist practice ${ }^{17}$.

\footnotetext{
${ }^{12}$ I. Biliarsky, Two Documents Concerning the Matrimonial Relations amongst the Balkan Jews in the Late Middle Ages, [in:] To Be or Not to Be a Jew. On Conversion to or Renouncing Judaism, ed. A. Cornea, M. Stanciu, Bucarest 2014, p. 141-147.

${ }^{13}$ R. Gradeva, Apostasy in Rumeli in the Middle of the Sixteenth Century, [in:] Rumeli Under the Ottomans: $15^{\text {th }}-18^{\text {th }}$ Centuries. Institutions and Communities, Istanbul 2004, p. 287-368.

${ }^{14}$ Ibidem, p. 296.

${ }^{15}$ C. Ginzburg, Il nicodemismo. Simulazione e dissimulazione religiosa nell'Europa del '500, Torino 1970.

${ }^{16}$ Cf. S. Skendi, Crypto-Christianity in the Balkan Area..., p. 227; about religious coexistence in Spain, where the new conversos were often suspected or accused of apostasy, see, for instance, G. Fiume, La cacciata dei moriscos e la beatificazione di Juan de Ribera, Brescia 2014; Identidades cuestionadas. Coexistencia y conflictos interreligiosos en el mediterráneo (ss. XIV-XVIII), ed. B. Franco, B. Pomara, M. Loma, B. Ruiz, Valencia 2016; F. Alfieri, Espellere $i$ «moriscos», [in:] Introduzione alla storia moderna, ed. V. Lavenia, M. Bellabarba, Bologna 2018, p. 335-344. ${ }^{17}$ N. Malcolm, Crypto-Christianity..., p. 97-98.
} 
In fact, we must admit that similar practices were widespread in the Ottoman Balkans, since religious identities and boundaries were often blurred. For instance, Muslims, Orthodoxies and Catholics used to take part in common celebrations or prayers before the same sacred images, as was the case in Olovo (present day Bosnia), where an icon of the Virgin, considered to be miracle-working, was commonly worshipped as people sought remedies against diseases ${ }^{18}$.

But interestingly enough we do have an earlier document proving the proper existence of crypto-Christianity. In 1599, Vincenzo di Augustino, a chaplain from Dubrovnik serving as a missionary in the Ottoman Buda, sent a report to the Holy Office which turns out to be extremely relevant to our analysis. It was discovered and published by the Hungarian historian Antal Molnar in $2013^{19}$.

${ }^{18}$ M. Balázs, A. Fricsy, L. Lukács, I. MonoK, Erdélyi és hodoltsági jezsuita missiok, vol. I.1, 16091616, Szeged 1990.

${ }^{19}$ A. Molnár, A Chaplain from Dubrovnik in Ottoman Buda: Vincenzo di Augustino and his Report to the Roman Inquisition about the Situation of the Balkan Catholicism, DAn 18, 2014, p. 95-121.

I recently focused on earlier examples of crypto-Christianity. In the unpublished autobiography of Giulio Mancinelli SJ, a missionary in the Balkans from 1575-1576 (he spent about two years in the Ragusa area - in present day Dubrovnik, Croatia) and again in 1583 on his way to Constantinople, where he was supposed to establish a Jesuit mission, he sheds more light on the matter.

Father Mancinelli began his life story in 1602, and provided a detailed account of his pastoral activities, travels and religious experiences. In Chapter 8, Delle missioni et viaggi che fece nelle parti della Turchia [Missions and travels in the Ottoman Empire], he carefully describes a very interesting practice: Trovò che turchi, cioè i rinegati di quei paesi alli turchi soggetti, facevano occultamente battezzare i loro figliuoli, celebrare le nozze dal curato et benedire le sepulture di loro morti al modo christiano, essendo la maggior parte di loro restati d'animo christiano, solamente per certi loro interessi della robba, preso quella setta nello esteriore (M. KoRADE, Julije Mancinelli o dubrovačkoj okolici (1575/76), "Vrela i Prinosi" 16, 1986, p. 148. To the best of my knowledge, only the few pages about Mancinelli's first stay in Ragusa have been published in the aforementioned article). Christian people who converted to Islam, he wrote, commonly used to celebrate marriage, administer baptism and bury their dead according to Christian religious and ritual traditions, since they publicly acted as Muslims but secretly still identified themselves otherwise: according to Father Mancinelli, they merely pursued their economic interest by converting to Islam. Mancinelli thus verifies that cryptoChristianity was becoming commonplace in the second half of the $16^{\text {th }}$ century.

But there is a second, yet unpublished evidence of crypto-Christianity which involves the Balkan peninsula and deserves a special attention. During his stay in Constantinople (1583-1585), Mancinelli bumped into a "Turk", who came out as a former captain of Italian origin, Urbano from Ferrara. This men described his life, military and religious experience very carefully. He used to serve as a Captain, but eventually he became the head of a gang of bandits. Being a criminal, he was seriously unpopular among the Italian princes and nobles and subsequently forced to flee abroad, seeking refuge in Kotor (Catarro) and then in Hercegnovi (Castel nuovo del Turco) to avoid arrest. Unfortunately, the Republic of Venice kept looking for him. So Urbano converted to Islam and the local voivode helped him reach Constantinople, where he settled being identified as a proper muslim. Queste cose dicendo amaramente piangeva sospirando, et per segnale chei era interiormente christiano, si cavò dalla tasca la corona, quale soleva dire ogni giorno (ARSI, Vita 19, f. 104v.). So he publicly decided to embrace Islam, but secretly kept professing Christianity. He was desperate and 
The Ragusan chaplain, in his letter to Cardinal Giulio Antonio Santoro, attempted to summarise the problems that missionaries and priests had to face in the Ottoman Balkans. As the chaplain explains, he had often met Muslim people (qualche Turco) claiming they had been forced to embrace the Islamic religion, being captured by the Ottomans. But secretly, those people - who used to be Christian (fui Cristiano) - kept worshipping the Christian God and preaching about the Virgin. Those crypto-Christians asked for the missionary's absolution and forgiveness, but di Augustino did not know how to handle the matter and wrote to the Holy Office in Rome asking for instructions.

As far as I am concerned, this proves that in 1599 the practice was already consolidated and more than likely used as a concrete strategy and a custom. In another similar but later case we could look at the report written by Marino Bizzi in $1622^{20}$. As the archbishop of Antivari, he undertook a visitation and subsequently sent a letter to the newly formed Congregation de Propaganda Fide in Rome. He had noticed that so-called "secret" or "hidden" Christianity was quite common among Albanians: they only converted to Islam to avoid persecution and tax burdens, he claimed.

As Leften Stavrianos pointed out in his book The Balkans since 1453, generally speaking Christians suffered from various disabilities and discrimination but despite this, they enjoyed more freedom than did the various minorities in contemporary Christendom ${ }^{21}$. As a result, the Ottoman conquest did not achieve a mass conversion throughout the Balkan peninsula. That occurred only in a few specific regions such as Bosnia and Albania.

Jews and Christians (both Orthodoxies and Catholics), as non-Muslims, enjoyed the legal status of dhimmitude, which was, in fact, a tool able to combine both tolerance and intolerance in a flexible, coherent and relatively efficient policy ${ }^{22}$.

keen on seeking redemption: to prove his sincerity, he showed the little crown he used for his prayer. Hopefully, I will be able to devote more attention to this evidence in the near future as I recently started working on Mancinelli's autobiograhy. However, we can say that even in this peculiar case, crypto-Christianity is described by Mancinelli as a strategy and a useful ploy used to avoid an unpleasant consequence.

${ }^{20}$ This report was previously unknown since Antal Molnar found it and published it in 2013. Cf. A. Molnár, A Dél-Balkán Képe Rómában. Marino Bizzi antivari érsek kéet kiadatlan beszámolója Szerbiáról és Albániáró (1622) [The Roman View of the Southern Balkans. Two unpublished reports by Archbishop Marino Bizzi of Antivari on Serbia and Albania (1622)], [in:] IDEM, Kalmárok és Káplánok az oszmán birodalomban. Források és tanulmányok a balkáni és hodoltági katolicizmus 16-17. Századi történetéhez, Budapest 2013, p. 131-135. Marino Bizzi identifies himself as the Arciverscovo di Antivari humilissimo servitore delle vostre signorie illustrissime e reverendissime [...] capo spirituale d'una numerosa christianità fra i Turchi nei Regni di Macedonia, Albania, Servia e Bulgaria (p. 131).

${ }^{21}$ L.S. Stavrianos, The Balkans since 1453, New York 2000, p. 105.

${ }^{22}$ R.-D. Chelaru, Between Coexistence and Assimilation: Catholic Identity and Islam in the Western Balkans (Seventeenth-Eighteenth Centuries), RI 23.3/4, 2012, p. 291-324. 
This odd legal position allowed Christian people to preserve their religious faith. As I said earlier, people were not forced to embrace the Islamic religion, as the Jesuit missionary Marino de Bonis also stated in a letter written in 1617: in Turchia è libertà di coscienza ed ad ogn'uno è lecito professar la fede che vole ${ }^{23}$ [in the Ottoman land people experienced a certain freedom when it came to freedom of religions].

But to do so Christians and Jews had to pay an additional tax, known as cizye. By paying this specific poll-tax, those people could rely on a guarantee of protection but in fact they were also relegated to a subordinate legal and social status, being subjected to a set of discriminatory rules which regulated their duties and boundaries and governed interreligious relations. As the scholar Eleni Gara aptly states, those who failed to follow these rules could experience serious reprisals and consequences, including enslavement and death ${ }^{24}$.

This Ottoman custom could pave the way for conversions to Islam - being considered as a part of the Muslim community was undoubtably useful in terms of economic and political advantages, especially for $\operatorname{men}^{25}$. For this reason, the need to be publicly and socially identified as Muslim is not surprising at all. It did not matter whether conversions to Islam were simulated or authentic ${ }^{26}$. In di Augustino's aforementioned paper, for instance, the chaplain mentioned the existence of another custom which was widespread among the Balkan Catholics: Christian people travelling with "Turks" during Lent often stopped fasting and consumed meat and dairy products since they preferred not to be identified as Christians.

I would like to broaden our discussion to look at another example. The Jesuit missionary Marino de Bonis claimed in a report written in 1617 from Belgrade that Catholics in "Servia, Slavonia et Ungheria" used to live surrounded by "enemies" (namely Turks, 'Schismatics', Lutherans, Calvinists) ${ }^{27}$. Moreover, as proven by accounts of some missionaries, Balkan Catholic communities often suffered from

\footnotetext{
${ }^{23}$ M. Balázs, A. Fricsy, L. Lukács, I. Monok, Erdélyi és hodoltsági jezsuita missiok..., p. 299.

${ }^{24}$ E. Gara, Conceptualizing Interreligious Relations in the Ottoman Empire: the Early Modern Centuries, APH 116, 2017, p. 59. In her essay Eleni Gara effectively summarises the variety of interpretations and theories about the alleged Ottoman tolerance towards non-Muslims living within the empire. As a matter of fact, this is a concept which has been extensively discussed by scholars and researchers. In this regard, she puts the accent on the shift from an emphasis on the oppression of the non-Muslims to that on toleration (p. 87).

${ }^{25}$ R.-D. Chelaru, Between Coexistence and Assimilation..., p. 22.

${ }^{26}$ About conversions see T. KRstić, Contested Conversions to Islam. Narratives of Religious Change in the Early Modern Ottoman Empire, Stanford Cal. 2011.

${ }^{27}$ Tra li fiumi Savo, Dravo, Drino e Danubio si trova infinito numero di christiani miserabilissimi che stanno nelle province di Servia, Slavonia et Ungheria [...]. Questi popoli sono di natione ungara e slavon, e stanno sotto l'acerbissimo a tirannico dominio de' turchi, e sono atorniati da ogni banda di heretici, luterani, ariani, calvinisti, anabatisti, ed altri scismatici; $i$ quali come tanti lupi arrabiati non cessano di scannare quelle povere pecorelle con acutissimi denti dei loro falsi e perversi dogmi; onde molte migliaia di persone hanno lasciato la vera cattolica religione et abbraciato la loro maledette setta (M. BALÁzs, A. Fricsy, L. LuKács, I. Monok, Erdélyi és hodoltsági jezsuita missiok..., p. 298).
} 
a severe lack of financial support and they were in need of educated priests. This situation - De Bonis stated - could trigger conversions from one religious confession (in this case Catholic) to another (i.e. Orthodox Christianity) ${ }^{28}$. Furthermore, the buildings used for religious services were frequently shared - thus, Balkan Catholics could often end up carrying out unusual rituals and "schismatic" celebrations, some of which were described by the missionaries in terms of superstition and magic ${ }^{29}$. This particular kind of coexistence necessarily determined an overlap among religious customs. In other words, the $17^{\text {th }}$-century multi-confessional Balkans represented an ideal breeding ground for ritual hybridisation as clear-cut religious boundaries and identities could hardly exist in that peculiar context. As Antal Molnár has pointed out,

in contrast with the Tridentine church model, Balkan Catholicism was characterised by transconfessional links, deficiencies in indoctrination, severe and irremediable problems of church discipline, and uncertain jurisdictional boundaries ${ }^{30}$.

Of course, when thinking about hidden Christianity, one should not forget this complex religious and cultural jigsaw, where so many confessional groups lived together. From this perspective, crypto-Christianity could be seen as a significant part of a strongly enmeshed system.

In this regard, one more issue should be mentioned here. The $16^{\text {th }}$ and $17^{\text {th }}$ centuries have been defined as the "age of confessionalisation" in Western Europe: Christian confessions (Lutheranism, Catholicism, and Calvinism) penetrated all layers of spiritual, social, public and private life, functioning as a regulatory agent and shaping the society itself. Heinz Schilling and Wolfgang Reinhard, who are considered to be the fathers of this paradigm, define confessionalisation as the first phase of early modern absolutism or "social disciplining" 31 .

Can this be applied to Balkan Catholicism? Undoubtably the papacy attempted to standardise and regulate Balkan Catholicism and the lives of the people, and

\footnotetext{
${ }^{28}$ Ibidem.

${ }^{29}$ Cf. ibidem, p. 299.

${ }^{30}$ A. Molnár, Confessionalization on the Frontier..., p. 10.

${ }^{31}$ Cf. H. Schilling, From Empires to Family Circles: Religious and Cultural Borderlines in the age of Confessionalisation (with I. G. Tóth), [in:] Cultural Exchange in..., p. 25-46; IDEM, La confessionalisation et le système international, [in:] L'Europe des traitésde Westphalie. Esprit de la diplomatie ed diplomatie de l'esprit, ed. L. BELY, Paris 2000, p. 411-428; IDEM, Confessione e identità politica in Europa agli inizi dell'età moderna (XV-XVIII secolo), C.RIT 6, 1995, p. 970-983; IDEM, Konfessionalisierung und Formierung eines internationalen Systems während der frühen Neuzeit, [in:] Die Reformation in Deutschland und Europa. Interpretationen und Debatten, ed. H. Guggisberg, G. KrodeL, Gütersloh 1993, p. 597-613; W. ReInhaRD, Stato e modernità, [in:] Le radici storiche dell'Europa. L'età moderna, ed. M.A. Visceglia, Roma 2007, p. 25-37; IDEM, Il pensiero politico moderno, Bologna 2000; IDEM, Confessionalizzazione forzata? Prolegomeni ad una teoria dell' età confessionale, AISIT 8, 1982, p. 13-38.
} 
intended to do so through its missionaries, genuine agents of Catholic confessionalisation on the last frontier of European Christianity. But as we already noted, the Balkan framework was completely different, being characterised by an endemic lack of homogeneity. Moreover, that territory was part of the Ottoman Empire, a powerful state in the Islamic world.

Therefore, the documents we referred to are extremely relevant since they very neatly show the reality that missionaries used to face while carrying out their pastoral duties: sometimes they had to mediate between the endemic features of the mission territory and Catholic orthodoxy and orthopraxy. For this reason, on several occasions they ended up tolerating ambiguous practices, such as hidden Christianity ${ }^{32}$. From this perspective, crypto-Catholicism could certainly be considered as one of the many faces of the unsuccessful attempt at confessionalisation in the Ottoman Balkans.

\section{Bibliography}

\section{Primary Sources}

Balázs M., Fricsy A., Lukács L., Monok I., Erdélyi és hodoltsági jezsuita missiok, vol. I.1, 1609-1616, Szeged 1990.

Molnár A., A Chaplain from Dubrovnik in Ottoman Buda: Vincenzo di Augustino and his Report to the Roman Inquisition about the Situation of the Balkan Catholicism, "Dubrovnik Annals" 18, 2014, p. 95-121, https://doi.org/10.21857/m8vqrt05k9

Molnár A., A Dél-Balkán Képe Rómában. Marino Bizzi antivari érsek kéet kiadatlan beszámolója Szerbiáról és Albániáró (1622), [in:] A. MolnáR, Kalmárok és Káplánok az oszmán birodalomban. Források és tanulmányok a balkáni és hodoltági katolicizmus 16-17. Századi történetéhez, Budapest 2013.

VAnino M., Autobiografija Bartola Kašića, Zagreb 1940 [= Građa za povijest književnosti hrvatske, 15].

\section{Secondary Literature}

Alfieri F., Espellere $i$ «moriscos», [in:] Introduzione alla storia moderna, ed. V. LAVENIA, M. BellaBARBA, Bologna 2018, p. 335-344.

Bénat Tachot L., Gruzinski S., Passeurs culturels. Mécanismes de métissage, Paris 2001.

Biliarsky I., Two Documents Concerning the Matrimonial Relations amongst the Balkan Jews in the Late Middle Ages, [in:] To Be or Not to Be a Jew. On Conversion to or Renouncing Judaism, ed. A. Cornea, M. Stanciu, Bucarest 2014, p. 141-147.

Chelaru R.-D., Between Coexistence and Assimilation: Catholic Identity and Islam in the Western Balkans (Seventeenth-Eighteenth Centuries), "Revista istorică" 23.3-4, 2012, p. 291-324.

${ }^{32}$ Cf. Collectanea S. Congregationis de Propaganda Fide, seu decreta, instructiones, rescripta pro Apostolicis Missionibus I (1622-1866), Romae 1907. 
Collectanea S. Congregationis de Propaganda Fide, seu decreta, instructiones, rescripta pro Apostolicis Missionibus I (1622-1866), Romae 1907.

Fiume G., La cacciata dei moriscos e la beatificazione di Juan de Ribera, Brescia 2014.

GARA E., Conceptualizing Interreligious Relations in the Ottoman Empire: the Early Modern Centuries, "Acta Poloniae Historica" 116, 2017, p. 57-91.

Ginzburg C., Il nicodemismo. Simulazione e dissimulazione religiosa nell'Europa del '500, Torino 1970.

Gradeva R., Apostasy in Rumeli in the Middle of the Sixteenth Century, [in:] Rumeli Under the Ottomans: $15^{\text {th }}-18^{\text {th }}$ Centuries. Institutions and Communities, Istanbul 2004, p. 287-368.

Identidades cuestionadas. Coexistencia y conflictos interreligiosos en el mediterráneo (ss. XIV-XVIII), ed. B. Franco, B. Pomara, M. Loma, B. Ruiz, Valencia 2016.

Korade M., Julije Mancinelli o dubrovačkoj okolici (1575/76), “Vrela i Prinosi” 16, 1986, p. 131-151.

KRstić T., Contested Conversions to Islam. Narratives of Religious Change in the Early Modern Ottoman Empire, Stanford Cal. 2011.

Malcolm N., Crypto-Christianity and Religious Amphibianism in the Ottoman Balkans. The Case of Kosovo, [in:] Religious Quest and National Identity in the Balkans, ed. H. Norris, M. HePpell, C. HaWKesWorth, London 2001, p. 91-110.

Malcolm N., Kosovo. A Short History, New York 1998.

Molnár A., Confessionalization on the Frontier. The Balkan Catholics between Roman Reform and Ottoman Reality, Roma 2019.

Molnár A., Le Saint-Siège, Raguse et les missions catholiques de la Hongrie ottomane 1572-1647, Roma-Budapest 2007.

Ndreca A., L'Albania nell' Archivio di Propaganda Fide, Città del Vaticano 2017.

Pizzorusso G., Governare le missioni, conoscere il mondo nel XVII secolo. La Congregazione pontificia De Propaganda Fide, Viterbo 2018.

Reinhard W., Confessionalizzazione forzata? Prolegomeni ad una teoria dell'età confessionale, "Annali dell'Istituto Storico Italo-germanico in Trento" 8, 1982, p. 13-38.

ReINHARD W., Il pensiero politico moderno, Bologna 2000.

ReInHARd W., Stato e modernità, [in:] Le radici storiche dell'Europa. L'età moderna, ed. M.A. VIsCEGLIA, Roma 2007, p. 25-37.

Schilling H., La confessionalisation et le système international, [in:] L'Europe des traitésde Westphalie. Esprit de la diplomatie ed diplomatie de l'esprit, ed. L. BeLY, Paris 2000, p. 411-428.

SchIlling H., Confessione e identità politica in Europa agli inizi dell' età moderna (XV-XVIII secolo), "Concilium. Rivista internazionale di Teologia" 6, 1995, p. 970-983.

Schilling H., From Empires to Family Circles: Religious and Cultural Borderlines in the age of Confessionalisation (with I. G. Tóth), [in:] Cultural Exchange in Early Modern Europe, vol. I, Religion and Cultural Exchange in Europe, 1400-1700, ed. H. Schilling, I.G. Tóth, Cambridge 2007, p. 25-46.

Schilling H., Konfessionalisierung und Formierung eines internationalen Systems während der frühen Neuzeit, [in:] Die Reformation in Deutschland und Europa. Interpretationen und Debatten, ed. H. Guggisberg, G. Krodel, Gütersloh 1993, p. 597-613.

Skendi S., Crypto-Christianity in the Balkan Area under the Ottomans, "Slavic Review" 26.2, 1967, p. 227-246.

StaVRIANos L.S., The Balkans since 1453, New York 2000. 
Tо́тн I.G., Missionaries as Cultural Intermediaries in Religious Borderland: Habsburg Hungary and Ottoman Hungary in the Seventeenth Century, [in:] Cultural Exchange in Early Modern Europe, vol. I, Religion and Cultural Exchange in Europe, 1400-1700, ed. H. Schilling, I.G. Tóth, Cambridge 2007, p. 88-110.

ZEFi S., Islamizacija Albanaca i fenomen ljaramanstva tijekom stoljeća (XV.-XX.). Razlozi i stav Katoličke crkve, Zagreb 2003.

\begin{abstract}
In this paper I intend to address the issue of crypto-Catholicism in the early Ottoman Balkans, a complex phenomenon which has drawn historians' attention over the decades. More specifically, I will attempt to define and clarify the difficult and unresolved issue, taking into account the characteristics of the Balkans where many religious and social groups co-existed. That produced interaction and enmeshment between the various religions and, as a result, identities developed specific distinctive traits and often overlapped.

Within that unique Balkan environment - a real confessional melting pot - crypto-Christianity naturally arose. Crypto-Catholics or Orthodoxies, living under Ottoman rule, publicly decided to embrace the Islamic religion but secretly identified themselves as Christians. I have set out to investigate this phenomenon by considering letters and reports produced by Catholic missions involved in the Balkan peninsula.
\end{abstract}

Keywords: Ottoman Balkans, Catholic missionaries, crypto-Christianity, Catholic confessionalisation

Silvia Notarfonso

Eötvös Loránd University

Egyetem tér 1-3

Budapest, 1053 Hungary

University of Macerata

Via Giovanni Mario Crescimbeni, 30/32

62100 Macerata MC, Italy

s.notarfonso@gmail.com 